\title{
Relation between nutrition and fertility in pigs
}

\author{
L. A. den Hartog and G. J. M. van Kempen \\ Department of Animal Nutrition, Agricultural University, Haagsteeg 4, 6708 PM \\ Wageningen, the Netherlands
}

Accepted: 6 August 1980

Key words: energy intake, age at puberty, ovulation rate, conception rate, embryonic survival, fertility, gilt

\section{Summary}

Data from trials on the influence of intake of energy and protein on fertility in gilts were collected. According to calculations from several of the trials a high energy intake shortly before oestrus (flushing) increased ovulation rate. A low energy intake during rearing resulted in a fewer number of ovulations than a high energy level. But most or all of the favourable effect decreased because of a higher embryonic mortality. The sequence low, high, low for energy level during rearing, flushing and early pregnancy, respectively, seemed best. However, 3 out of 8 possible combinations have been widely studied.

\section{Introduction}

Before trials were started, we searched the literature on the relation between nutrition and fertility in pigs. The following characteristics were examined: age and weight at puberty; number of ovulations; conception rate; and embryonic survival.

Much research work has been undertaken on the relationship between nutrition and fertility in pigs. It is rather difficult to compare the different studies in this field because conditions in trials are so different: for example the age of the pigs and the kind of quantity (e.g. gross or net energy) or units (e.g. kcal or MJ) in which the requirements of the pigs are expressed are not the same. Another problem is that most trials are rather small and variation may be wide. Especially for studies on fertility, there is a need for large-scale experiments. Mostly nutrition or level of feeding is only a part of a wider aim. Joosten (1979) reviewed literature about the relationship between energy and fertility in pigs. He processed the data from literature to make it as comparable as possible. He used only exact data and expressed all the feeding levels as net energy rate for fattening $\left(\mathrm{NE}_{\mathrm{F}}\right)(\mathrm{MJ} / \mathrm{d})$ as is usual for pig nutrition in the Netherlands. The factors he used were: digestible energy $(\mathrm{DE})=0.8 \times$ gross energy $(\mathrm{GE})$; metabolizable energy $(\mathrm{ME})=0.96 \times \mathrm{DE} ; \mathrm{NE}_{\mathrm{F}}=0.70 \times \mathrm{ME}$. 
In our study, we used statistical methods to combine the results of different studies on the influence of energy intake on reproduction in pigs and summarized a larger literature review of den Hartog (1980).

\section{Material and methods}

Data used for statistical processing were taken from 48 studies. The following characteristics were studied: embryonic survival, ovulation rate, age and weight at puberty and conception rate. The periods under study were: rearing, shortly before oestrus (flushing) and early pregnancy. Not all the possible combinations of treatments were covered in each study. We always compared treatments for each publication, since the factor publication brings together many variables like breed, season, housing and management.

In the statistical study, the following associations of food intake and reproduction traits were screened:

- energy intake during rearing with age and weight at puberty

- energy intake during rearing with ovulation rate

- energy intake shortly before oestrus with ovulation rate

- feeding level during rearing with conception rate

- energy intake during different periods with embryonic survival.

The periods were rearing, shortly before oestrus and early pregnancy.

The results of the different studies on the relation between food intake and fertility characteristics were combined by analysis of variance or covariance.

\section{Results and discussion}

Age and weight at puberty

\section{Energy restriction}

A gilt should reach puberty in a good condition and at an early age. Each day of delay in the first litter corresponded to a decrease of 0.02 to 0.03 piglets per sow per year (Legault \& Dagorn, 1973). Before an age of 9 months, $60-90 \%$ of gilts showed oestrus (Christenson \& Ford, 1979). Swedish Landrace gilts reached puberty significantly earlier than Hampshire, Large White and Duroc gilts $(\mathrm{p}<0.01)$. The heritability $\left(h^{2}\right)$ of age and weight at puberty was 0.46 and 0.44 respectively (Legault, 1973). There are still other major factors influencing age and weight at puberty. Factors which reduce age at puberty according to Hughes \& Cole (1975) are:

1. moving gilts to another pen (at a weight of about $55 \mathrm{~kg}$ )

2. daily contact with a boar (from a weight of about $64 \mathrm{~kg}$ )

3. genetic factors

4. ad libitum feeding during rearing.

Moving gilts to another pen and daily contact with a boar accelerate puberty (du Mesnil du Buisson \& Signoret, 1962; Te Brake, 1975; Thompson \& Savage, 1978). There is disagreement on the effect of nutrition on age and weight at puberty (Anderson \& Melampy, 1972; Brooks \& Cole, 1974; Rerat \& Duée, 1975). Table 1 
Table 1. Influence of energy or food restriction during rearing on age at puberty. There was calculated whether age at puberty was significantly increased or decreased by food restriction. If the effect was not significant, trials with 5 or more days difference were added to the trials with a significant effect. A decrease in age at puberty was taken as favourable and an increase as unfavourable.

Authors who found a

favourable effect

Self et al. (1955)**

Gosset \& Sørensen (1959)

Hafez (1960)

Aherne et al. (1976)

McPherson et al. (1977)**
Authors who found

no effect

Christian \& Nofziger (1952)

Lodge \& McPherson (1961)

Sørensen et al. (1961)

Holness (1972)

Pay \& Davies (1973)

Etienne \& Legault (1974)

Friend (1977)

Schilling \& Schröder (1977)
Authors who found
an unfavourable effect

Robertson et al. (1951)

Burger (1952)

Haines et al. (1959)**

Zimmerman et al. (1960b)*

Goode et al. (1965)*

O'Bannon et al. (1966)**

Holness (1972)*

\{ Etienne \& Duée (1973)**

\{ Duée \& Etienne (1974)**

Friend (1976)**

(van de Kerk \& Elsinghorst

$\left\{(1976)^{*}\right.$

van Kempen (1976)*

Schilling \& Schröder (1977)

Hermann \& Richter (1979)

Significant difference: ${ }^{*} \mathrm{P}<0.05 ; * \mathrm{P}<0.01$.

shows this inconsistency.

For statistical processing data of the following authors gave sufficient information. Robertson et al. (1951), Burger (1952), Christian \& Nofziger (1952), Self et al. (1955), Gosset \& Sørensen (1959), Haines et al. (1959), Hafez (1960), Zimmerman et al. (1960b), Lodge \& McPherson (1961), Sørensen et al. (1961), Goode et al. (1965), O'Bannon et al. (1966), Etienne \& Duée (1973), Pay \& Davies (1973), Friend (1977), van Kempen (1976), Aherne et al. (1976), Friend (1977), McPherson et al. (1976) and Schilling \& Schröder (1977). Overall correlation coefficients between energy intake and age and weight at puberty were calculated firstly. Age at puberty is negatively correlated with average daily gain (Table 2 ). This result is in agreement with data of Aherne \& Price (1979), who found, within the group that came to ovulation during their trial, a negative correlation $(r=-0.569 ; \mathrm{P}<0.001)$ between age at puberty and average daily gain. The average daily gain for pigs that reached puberty earlier, was lower than that for pigs that did not reach puberty. They used an equal feeding level for all the pigs.

Analysis of covariance was performed with age and weight at puberty as dependent and publication and feeding level (high or low) as independant variables. Age of the gilts at the start of the trial was taken as a covariable. Means of (adjusted) variables at low and high levels of energy intake are given in Table 3. Restrictedly fed gilts reached puberty significantly later ( 9 days) and with a significantly lower weight $(19.1 \mathrm{~kg})$ than gilts on a high feeding level.

For correct evaluation of data it is necessary to forecast when gilts that did not 
Table 2. Overall correlation coefficients ( $r$ ) of energy intake during rearing with age and weight at puberty ( $\mathrm{n}$ is number of trials).

\begin{tabular}{lccc}
\hline Correlation of & $\mathrm{n}$ & $\mathrm{r}$ & $\begin{array}{c}\text { Signifi- } \\
\text { cance (P) }\end{array}$ \\
Age at puberty and daily energy intake & & & \\
Age at puberty and average daily gain & 38 & -0.02 & 0.450 \\
Age at puberty and weight at puberty & 34 & -0.41 & 0.008 \\
Weight at puberty and daily energy intake & 50 & +0.57 & 0.001 \\
Weight at puberty and average daily gain & 37 & +0.49 & 0.001 \\
Average daily gain and daily energy intake & 34 & +0.41 & 0.009 \\
\hline
\end{tabular}

Table 3. Relation of intake of net energy for fattening $\left(\mathrm{NE}_{\mathrm{F}}\right)$ during rearing with age and weight at puberty ( \pm separates mean and standard deviation).

\begin{tabular}{lllll}
\hline & $\begin{array}{l}\text { Low } \\
\text { intake }\end{array}$ & $\begin{array}{l}\text { High } \\
\text { intake }\end{array}$ & $\begin{array}{l}\text { Significance of Coefficient of } \\
\text { difference }(\mathrm{P})\end{array}$ \\
$\begin{array}{l}\text { Number of trials } \\
\text { variation }{ }^{2}(\%)\end{array}$ \\
$\begin{array}{l}\text { Average age at start (d) } \\
\text { Average weight at start }(\mathrm{kg})\end{array}$ & $86.7 \pm 27.9$ & 19 & & \\
$\begin{array}{l}\text { Average daily net energy } \\
\text { intake }(\mathrm{MJ} / \mathrm{d})\end{array}$ & $16.4 \pm 2.6(20)^{1}$ & $25.3 \pm 2.5(18)^{1}$ & & \\
Age at puberty (d) & 211 & $34.8 \pm 28.2$ & & \\
Weight at puberty (kg) & 80.0 & 99.1 & $<0.06$ & 6.8 \\
\hline
\end{tabular}

${ }^{1}$ The number in parenthesis is number of trials in which the energy intake was well defined and not only stated as high and low.

${ }^{2}$ Calculated from residual mean square.

reach oestrus would do so. Van Kempen (1976) used the method of censorated data to predict the age at puberty of all the gilts in his trial (oestrus or non-oestrus). By censorated data age at puberty is assumed to be normally distributed. Age at puberty for the oestrus gilts and for all gilts differed from 4 to 11 days for the experimental groups.

The critical time for development of the uterus and ovaries of gilts is assumed to be at 70-160 days from birth (Busch, 1976). According to Günther (1974), the development of the different organs follows certain rules. First nervous system and the important organs like heart, liver, kidneys and lungs develop. Then the muscles, bones, fat tissue and udder follow. Lastly energy from the ration goes to the reproductive organs. According to this hypothesis a deficiency of energy during rearing would probably first be seen in a decreased fertility. For reaching puberty age is more important than weight. Gilts which are very thin at a certain age will not reach puberty (McCance \& Widdowson, 1974). At the other side some investigations (left column in Table 1) showed a reduction in age at puberty with feed restriction during rearing. These two phenomena suggest that there are minimum and maximum fat contents of the body required which act as a threshold for reaching puberty. Be- 
tween these limits age is the determining factor. Perhaps pigs with thin backfat have relatively more internal fat. In human females, there is a difference in fat deposition between early and late sexual maturation (Frisch, 1975). Frisch mentioned three possibilities: (1) storage of oestrogen in fat depots affects blood levels of oestrogen, or other steroids or their secretion rates; (2) oestrogen metabolism may be influenced by factors in fat metabolism, including thyroid hormones; (3) fat content is important in regulating hypothalamus.

\section{Protein restriction}

For the effect of protein restriction during (part of) rearing, there is more agreement in the literature than about energy restriction (Table 4). Except for Robertson et al. (1951) and Naber et al. (1972), all the authors found no effect or an unfavourable effect of protein restriction on age at puberty. The protein given by Naber et al. (1972) had, however, an increased lysine content. More important than protein content would be the content of amino acids. Normally the first limiting amino acid for pigs is lysine. There is some evidence that only a severe inbalance in essential amino acids may delay the onset of puberty in gilts (Friend, 1973).

\section{Number of ovulations in gilts}

\section{Relation of energy intake during rearing with ovulation rate}

Generally number of corpora lutea is used as measure of number of ovulations. Mistakes are made when a fertilized ovum resulted in two or more embryos (polyembryony) or a follicle gives two or more ova (polyovuly). Polyembryony results in monozygotic (identical) twins. Among 80 pregnant sows Pomeroy (1960) found 2 with more embryos than corpora lutea. Table 5 gives the relation between feeding level during rearing and ovulation rate. A high feeding level during rearing generally increased number of ovulations.

For statistical evaluation of ovulation, publications of the following authors were studied: Robertson et al. (1951), Self et al. (1955), Haines et al. (1959), Gosset \&

Table 4. Influence of protein restriction during rearing on age at puberty. There was calculated whether age at puberty was significantly increased or decreased by protein restriction. If the effect was not significant, trials with 5 days or more difference were added to the trials with a significant effect. A decrease in age at puberty was taken as favourable and an increase as unfavourable.

\begin{tabular}{lll}
\hline $\begin{array}{l}\text { Authors who found a } \\
\text { favourable effect }\end{array}$ & $\begin{array}{l}\text { Authors who found } \\
\text { no effect }\end{array}$ & $\begin{array}{l}\text { Authors who found } \\
\text { an unfavourable effect }\end{array}$ \\
$\begin{array}{l}\text { Robertson et al. (1951)* } \\
\text { Naber et al. (1972)** }\end{array}$ & $\begin{array}{l}\text { Etienne \& Legault (1974) } \\
\text { Friend (1976) } \\
\text { Friend (1977) }\end{array}$ & $\begin{array}{l}\text { Holness (1972)** } \\
\text { Cunningham et al. (1974)** } \\
\text { Duée \& Etienne (1974) } \\
\text { Duée (1977) } \\
\text { Jones \& Maxwell (1974) } \\
\text { Wahlstrom \& Libal (1977)* }\end{array}$ \\
\hline
\end{tabular}

Significant difference: ${ }^{*} \mathrm{P}<0.05 ; * * \mathrm{P}<0.01$ 
Table 5. Influence of a high feeding level during rearing on the number of ovulations in gilts. If the number of ovulations is increased by 0.5 ovum, the effect is described as favourable.

\begin{tabular}{lll}
\hline Favourable effect & & No effect \\
Robertson et al. & $(1951)^{*}$ & Goode et al. \\
Christian \& Nofziger & $(1951)^{*}$ & \\
Self et al. & $(1955)^{* *}$ & \\
Haines et al. & $(1959)^{* *}$ \\
Gosset \& Sørensen & $(1960)$ \\
Hafez & $(1961)^{* *}$ \\
Sorensen et al. & $(1966)^{*}$ \\
O'Bannon et al. & $(1968)$ \\
Bazer et al. & $(1969)$ \\
Frobish \& Gerrits & $(1970)$ \\
Frobish & $(1972)^{*}$ \\
Brooks et al. & $(1973)^{*}$ \\
Etienne \& Duée & $(1976)$ \\
Duee \& Etienne & $(1976)$ \\
van Kempen & \\
van de Kerk \& Elsinghorst &
\end{tabular}

Significant difference: ${ }^{*} P<\overline{0.05} ;{ }^{* *} P<0.01$.

Sørensen (1959), Hafez (1960), Sørensen et al. (1961), Goode et al. (1965), O'Bannon et al. (1966), Christenson \& Zimmerman (1966), Bazer et al. (1968), Frobish \& Gerrits (1969), Frobish (1970), Brooks et al. (1972), Etienne \& Duée (1973) and van Kempen (1976). Normally number of ovaluations increased during the first three times of oestrus after reaching puberty. So oestrus number (first, second or third) was used as a covariable. Means of (adjusted) variables at low and high levels of energy intake are given in Table 6. Restricted energy intake during rearing resulted in significantly fewer ovulations than a high feeding level. Except for two publications, the low and high feeding levels fell into separate groups with slight overlap (Fig. 1). Anderson \& Melampy (1972) reviewed the results of 22 trials in which gilts received different intakes of net energy for 1-3 months before ovulation. The 'fullfed' gilts (about $25.1 \mathrm{MJ} / \mathrm{d}$ ) had 1.2 ovulations more than the restrictedly fed gilts (about 16.6 MJ/d).

Table 6. Number of ovulations after low and high energy intake during rearing ( \pm separates mean and standard deviation).

\begin{tabular}{llll}
\hline & $\begin{array}{l}\text { Number of } \\
\text { trials }\end{array}$ & $\begin{array}{l}\text { Intake of } \\
\text { energy }(\mathrm{MJ} / \mathrm{d})\end{array}$ & $\begin{array}{l}\text { Number of } \\
\text { ovulations }\end{array}$ \\
Low & 21 & $15.6 \pm 3.4$ & $11.8^{*}$ \\
High & 21 & $24.9 \pm 4.0$ & $13.2^{*}$ \\
\hline
\end{tabular}

* Significant difference $(<0.001)$.

1 Coefficient of variation (calculated from residual mean square) was $8.4 \%$. 


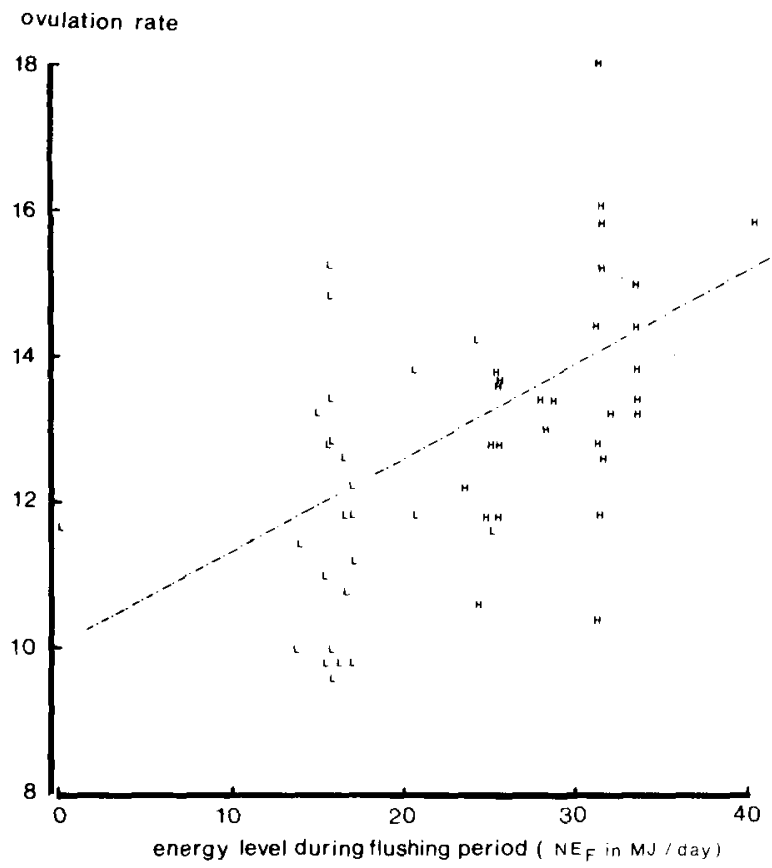

Fig. 1. Relation between energy level during rearing $(x)$ and ovulation rate $(y)$. $\mathrm{Y}=0.15 \mathrm{x}+9.41 ; \mathrm{r}=0.50 ; \mathrm{n}=44 ; \mathrm{P}<0.001$.

Relation of energy intake before oestrus with number of ovulations

A high feeding level before oestrus usually caused a significant improvement in number of ovulations (Table 7). A high feeding level on the day of oestrus had a positive effect on the number of corpora lutea; on the day after oestrus it had no effect. The increase with flushing on the day of mating could be due to rupture or regression of immature follicles. The number of corpora lutea increased, but not the number of ovulations (Brooks \& Cooper, 1972).

For the statistical evaluation we used results from the following authors: Self et al. (1955), Zimmerman et al. (1960a), McGillivray et al. (1962, 1963), Rigor et al. (1963), Short et al. (1963), Schultz et al. (1965), Kirkpatrick et al. (1967a, 1976b), Bazer et al. (1968), Clawson (1969), Frobish \& Gerrits (1969), Frobish (1970), Naber \& Zimmerman (1971, 1972), Brooks et al. (1972), Clark et al. (1972, 1973), Edey et al. (1972), Staigmiller et al. (1972), Moore et al. (1973), Daily et al. (1975), van Kempen (1976) and Emerson \& Henricks (1977). First we calculated the general correlation coefficient (r) and linear regression of average rate of intake of net energy during flushing with number of ovulations (Fig. 2). By covariance analysis with the factors high and normal energy intake and publication, we corrected for difference in duration of flushing. The average duration of flushing was $13.1 \pm 5.6$ days. In Table 8 the means of the traits with and without flushing are given. Flushing of gilts 
Table 7. Influence of flushing on the number of ovulations in gilts. If the number of ovulations is increased or decreased by 0.5 ovum, the effect is described as favourable or unfavourable, respectively.

\begin{tabular}{|c|c|c|c|c|}
\hline $\begin{array}{l}\text { Period of high feeding } \\
\text { level } \\
\text { 4-21 days before oestrus }\end{array}$ & $\begin{array}{l}\text { Favourable effect } \\
\text { Self et al. } \\
\text { Zimmerman et al. }\end{array}$ & & \multicolumn{2}{|c|}{$\begin{array}{l}\text { No }(N) \text { or unfavourable (U) } \\
\text { effect }\end{array}$} \\
\hline & $\begin{array}{l}\text { Self et al. } \\
\text { Zimmerman et al. } \\
\text { Zimmerman et al. } \\
\text { McGillivray et al. } \\
\text { McGillivray et al. } \\
\text { Rigor et al. } \\
\text { Short et al. } \\
\text { Schultz et al. } \\
\text { Schultz et al. } \\
\text { Kirkpatrick et al. } \\
\text { Kirkpatrick et al. } \\
\text { Bazer et al. } \\
\text { Moore et al. } \\
\text { Naber \& Zimmerman } \\
\text { Brooks et al. } \\
\text { Clark et al. } \\
\text { Dailey et al. } \\
\text { Edey et al. } \\
\text { Naber \& Zimmerman } \\
\text { Staigmiller et al. } \\
\text { Moore et al. } \\
\text { Dailey et al. } \\
\text { Dailey et al. } \\
\text { Emerson \& Henricks }\end{array}$ & $\begin{array}{l}(1955)^{* *} \\
(1958)^{* *} \\
(1960 \mathrm{a}) \\
(1962) \\
(1963) \\
(1963)^{* *} \\
(1963)^{*} \\
(1965)^{* *} \\
(1966)^{*} \\
(1967 \mathrm{a})^{*} \\
(1967 \mathrm{~b})^{*} \\
(1968)^{*} \\
(1971)^{* *} \\
(1971)^{*} \\
(1972) \\
(1972)^{* *} \\
(1972) \\
(1972)^{*} \\
(1972)^{* *} \\
(1972) \\
(1973)^{* *} \\
(1975 a) \\
(1975 b) \\
(1977)\end{array}$ & $\left\{\begin{array}{l}\text { van Kempen } \\
\text { van de Kerk \& } \\
\text { Elsinghorst }\end{array}\right.$ & $\begin{array}{l}(1976)(\mathrm{U}) \\
(1976)(\mathrm{U})\end{array}$ \\
\hline Day of oestrus & $\begin{array}{l}\text { Lodge \& Hardy } \\
\text { Moore et al. } \\
\text { Brooks et al. } \\
\text { Cooper et al. }\end{array}$ & $\begin{array}{l}(1968)^{*} \\
(1971)^{*} \\
(1972)^{*} \\
(1973)^{*}\end{array}$ & $\begin{array}{l}\text { Te Brake } \\
\text { Brooks \& Cooper } \\
\text { Brooks \& Cole } \\
\text { Naber \& Zimmerman } \\
\text { Libal et al. } \\
\text { Moore et al. }\end{array}$ & $\begin{array}{r}\text { 1971) cited by } \\
(1972)(\mathrm{N}) \\
(1971)(\mathrm{N}) \\
(1971)(\mathrm{N}) \\
(1972)(\mathrm{N}) \\
(1973)(\mathrm{N})\end{array}$ \\
\hline Day after oestrus & & & $\begin{array}{l}\text { Libal \& Wahlstrom } \\
\text { cited by Rerat \& Duée } \\
\text { Brooks et al. } \\
\text { Staigmiller \& First }\end{array}$ & $\begin{array}{r}(1970) \\
(1975) \\
(1972)(N) \\
(1973)(\mathrm{U})\end{array}$ \\
\hline
\end{tabular}

Significant difference: ${ }^{*} \mathrm{P}<0.05 ;{ }^{*} \mathrm{P}<0.01$.

has a positive effect on number of ovulations $(+1.9)$. The extra energy intake of the flushed gilts was on avered $82 \%$ more than of the unflushed gilts. Anderson \& Melampy (1972) also found in their literature review a positive effect of extra energy intake before oestrus on number of ovulations. From various investigations optimum duration of the high-energy regime seemed to be 11-14 days before expected data of oestrus or mating. At a low level of feeding ovulation rate in the gilt is under genetic 


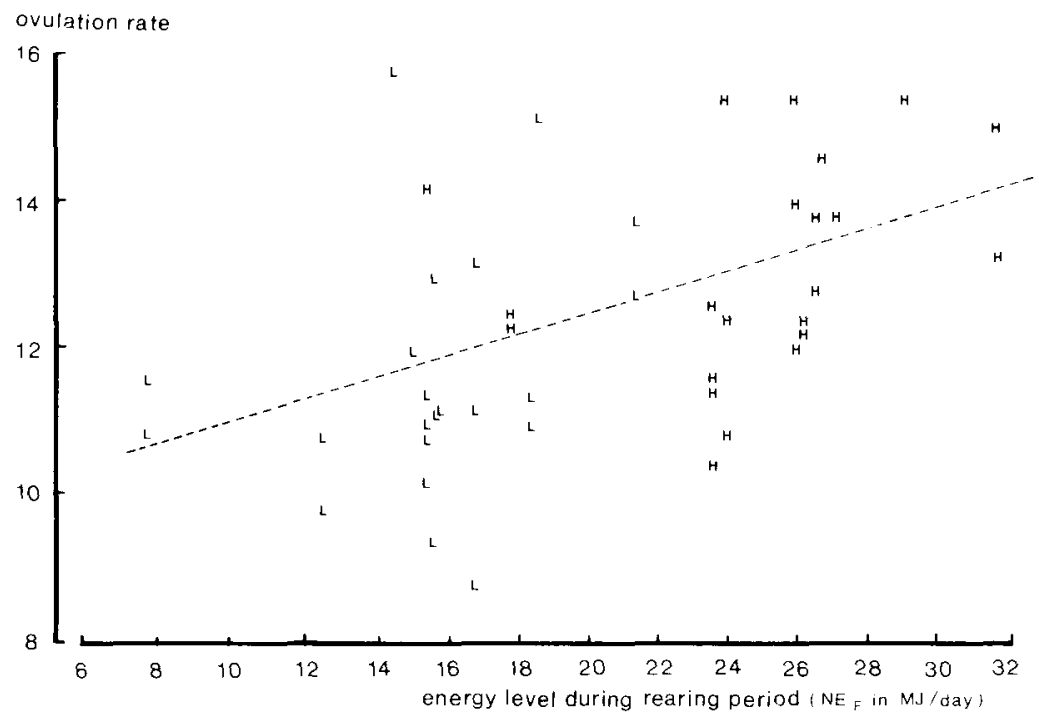

Fig. 2. Relation between energy level shortly before oestrus $(x)$ and ovulation rate $(y)$. $\mathrm{y}=0.12 \mathrm{x}+9.82 ; \mathrm{r}=0.54 ; \mathrm{n}=53 ; \mathrm{P} \ll 0.001$.

control. Short-term increases in dietary energy above maintenance increase number of ovulations (Brooks \& Coole, 1974). The favourable effect depends mainly on energy.

There were too few trials on flushing on the day of oestrus for statistical analysis.

\section{Relation of feeding level during rearing with conception rate}

There is no agreement in the literature on the influence of nutrition on conception rate (proportion of gilts becoming pregnant). Some research workers (Christian \& Nofziger, 1952; McGillivray et al., 1963; Myers \& Speer, 1963; Brooks et al., 1975; Etienne et al., 1976; Varley \& Cole, 1976) found no clear effect of feeding level on conception rate. Others (King \& Young, 1957; Lodge \& McPherson, 1961) found a higher conception rate for pigs on a high feeding scheme than in controls. Conception rate was studied for different sequences of feeding level during rearing and

Table 8. Influence of flushing on number of ovulations ( \pm separates mean and standard deviation).

\begin{tabular}{llll}
\hline & $\begin{array}{l}\text { Number of } \\
\text { trials }\end{array}$ & $\begin{array}{l}\text { Intake of } \\
\text { net energy }(\mathrm{MJ} / \mathrm{d})\end{array}$ & $\begin{array}{l}\text { Number of } \\
\text { ovulations }^{2}\end{array}$ \\
Low energy intake (no flushing) & 30 & $16.6 \pm 4.5(25)^{1}$ & $11.8^{*}$ \\
High energy intake (flushing) & 36 & $30.2 \pm 4.0(28)$ & $13.7^{*}$ \\
\hline
\end{tabular}

* Significant difference $(\mathrm{P}<0.001)$.

${ }^{1}$ In parenthesis the number of trials in which energy intake was well defined and not only stated as high and low.

${ }^{2}$ Coefficient of variation (calculated from residual mean square) was $8.8 \%$. 


\section{A. DEN HARTOG AND G. J. M. VAN KEMPEN}

Table 9. Conception rates for different sequences of feeding levels during rearing. The combinations of feeding levels were: low till mating (LL), high till mating $(\mathrm{HH})$ and low during rearing with flushing afterwards $(\mathrm{LH})$.

\begin{tabular}{lll}
\hline $\begin{array}{l}\text { Combination of } \\
\text { feeding levels }\end{array}$ & $\begin{array}{l}\text { Number of } \\
\text { trials }\end{array}$ & $\begin{array}{l}\text { Mean conception } \\
\text { rate }(\%)^{1}\end{array}$ \\
LL & 12 & 82.6 \\
LH & 6 & 88.0 \\
HH & 8 & 80.5 \\
\hline
\end{tabular}

${ }^{1}$ Coefficient of variation (calculated from residual mean square) was $14.3 \%$.

flushing. Data from the following authors were used: Gosset \& Sørensen (1959), Lodge \& McPherson (1961), O’Brannon et al. (1966), Schultz et al. (1966), Bazer et al. (1968), Lodge \& Hardy (1968), Frobish \& Gerrits (1969), Cooper et al. (1973), Moore et al. (1973), Pay \& Davies (1973), van Kempen (1976) and McPherson et al. (1977). The average conception rate in 26 trials was $83.2 \%$. A restricted feeding level during rearing followed by a flushing gave a higher conception rate than a continuously low or high feeding level (Table 9).

\section{Relation of feeding level with embryonic mortality}

According to a literature review of Te Brake (1975) prenatal mortality may be estimated at about $40 \%$. Most prenatal losses occur in the embryonic period, mainly before the 25th day after mating; during the foetal period (after 35 days of pregnancy; Wrathall, 1975), the mortality is less, presumably no more than $10 \%$ (Te Brake, 1975). Critical period for embryonic survival are during distribution in the uterus (11-13 d after mating), at implantation (13-23 d after mating) and during organ development (Hafez, 1959; Anderson, 1974). The greatest embryonic loss in farmstock seems to be at implantation, in contrast to the situation in rabbits, rats and mice where there are two peaks of losses, before and after implantation. The process of implantation is critical for correct balance of hormones; conditions suitable for blastocyst growth may not be suitable for implantation (Lamming, 1969). Many factors influence embryonic survival. According to Webel \& Dziuk (1974), embryonic mortality, first 30 days of pregnancy, does not result from lac of uterine capacity. They mentioned as possible causes for the high embryonic mortality: mistakes at fertilization or genetic aberrations.

A high energy intake by pregnant gilts has unfavourable effects like:

- increased embryonic mortality during early pregnancy

- more complications at farrowing

- more cases of low milk production

- a tendency for more fertility problems (Schneider \& Bronsch, 1975).

After flushing, it is advisable to reduce feed or energy level because of the increased chance of embryonic mortality (Robertson et al., 1951; Christian \& Nofziger, 1952, Self et al., 1966; Gosset \& Sørensen, 1959; Haines et al., 1959; Hanly, 1961; Sørensen et al., 1961; Dimov, 1963; Boyd, 1965; Goode et al., 1965; Tassel, 1967; Dutt \& Chaney, 1969; Frobish \& Gerrits, 1969; Lamming, 1969; Vanschou- 
broek, 1969; Englisch et al., 1971; Scofield, 1972; van Kempen, 1973, 1976; Wrathall, 1975; Hansel \& McEntee, 1977).

An energy deficiency during early pregnancy can result in:

- embryonic or foetal death followed by abortion or resorption

- malformations of embryo or foetus

- delay in development and growth of the foetus (Lamming, 1969).

For the statistical evaluation, trials of the following authors were screened: Robertson et al. (1951), Self et al. (1955), Haines et al. (1959), Gosset \& Sørensen (1959), Hafez (1960), Sørensen et al. (1961), Short et al. (1963), McGillivray et al. (1963), Goode et al. (1965), O'Bannon et al. (1966), Schultz et al. (1965, 1966), Christenson \& Zimmerman (1966), Bazer et al. (1968), Frobish \& Gerrits (1969), Libal \& Wahlstrom (1970), Frobish (1970), Naber et al. (1971), Brooks et al. (1972), Cooper et al. (1973), Etienne \& Duée (1973), Moore et al. (1973), van Kempen (1976) and Emerson \& Henricks (1977). The following variables were taken: number of days of pregnancy at slaughter; intake of net energy during rearing, flushing and pregnancy until slaughtering; number of embryos alive for the pregnant gilts; embryonic survival (number of embryos divided by number of corpora lutea) and publications. In total, 24 trials were screened. Generally a higher level of energy during rearing resulted in a higher embryonic mortality (Table 10). The higher feeding level during flushing resulted in more embryos per gilt. The average duration of pregnancy at the time of slaughter was $28.0 \pm 5.4$ days for the gilts. When the duration of pregnancy was longer, the embryonic mortality may be higher and the number of embryos alive per gilt smaller. So we used duration of pregnancy at slaughter as covariable in the analysis of variance. A high feeding level in the different periods always gave a higher embryonic mortality (Table 11). Higher embryonic mortality can result from a higher ovulation rate at the high energy level.

As yet the periods under study have been considered separately, but now they will be studied in relation to one other. A higher energy level during rearing and flushing seems to increase the number of ova shed. Effects of flushing may be influenced by feeding level in the preceding period (carry-over effects). With three periods studied (rearing, flushing and early pregnancy) and two energy levels, there are $2^{3}$ possible combinations. Not all these combinations have been studied. Only 3 combinations (LLL, LHL and $\mathrm{HHH}$ ) have been studied often (Table 12). We used covariance analyses only for these 3 combinations with duration of pregnancy at slaughter as covariable. A constant low energy level gave low embryonic mortality, but fewer ova were shed (Table 13). The calculated average number of ova shed was $12.6,13.9$

Table 10. Correlation coefficients ( $r$ ) of intake of net energy for fattening during several periods with embryonic survival and number of embryos alive.

\begin{tabular}{llll}
\hline Period & $\begin{array}{l}\text { Number of } \\
\text { trials }\end{array}$ & $\begin{array}{l}\text { Number of embryos } \\
\text { alive per gilt }\end{array}$ & $\begin{array}{l}\text { Embryonic } \\
\text { survival (\%) }\end{array}$ \\
Rearing & 55 & $-0.10(\mathrm{P}=0.23)$ & $-0.27(\mathrm{P}=0.02)$ \\
Flushing & 61 & $0.22(\mathrm{P}=0.04)$ & $-0.09(\mathrm{P}=0.24)$ \\
Early pregnancy & 59 & $0.07(\mathrm{P}=0.29)$ & $-0.06(\mathrm{P}=0.34)$ \\
\hline
\end{tabular}




\section{A. DEN HARTOG AND G. J. M. VAN KEMPEN}

Table 11. Difference between high and low feeding levels during different periods for reproduction traits ( \pm separates mean and standard deviation).

\begin{tabular}{|c|c|c|c|c|c|}
\hline Period & $\begin{array}{l}\text { Number of } \\
\text { trials }\end{array}$ & $\begin{array}{l}\text { Feeding } \\
\text { level }\end{array}$ & $\begin{array}{l}\text { Intake of net } \\
\text { energy }(\mathrm{MJ} / \mathrm{d})^{1}\end{array}$ & $\begin{array}{l}\text { Number of embryos } \\
\text { alive per gilt }{ }^{2}\end{array}$ & $\begin{array}{l}\text { Embryonic } \\
\text { survival } \\
(\%)^{2}\end{array}$ \\
\hline \multirow[t]{2}{*}{ Rearing } & 19 & $\operatorname{high}(\mathrm{H})$ & $26.3 \pm 3.1(17)$ & 9.8 & 69.7 \\
\hline & 46 & low (L) & $16.8 \pm 3.0(38)$ & 10.0 & 77.5 \\
\hline Difference (H-L) & - & - & 9.5 & $\begin{array}{l}-0.2 \\
(P=0.72)\end{array}$ & $\begin{array}{l}-7.8 \\
(P=0.01)\end{array}$ \\
\hline \multirow[t]{2}{*}{ Flushing } & 36 & high & $28.4 \pm 5.4(33)$ & 10.1 & 73.2 \\
\hline & 31 & low & $15.9 \pm 3.3(28)$ & 9.7 & 78.3 \\
\hline Difference $(\mathrm{H}-\mathrm{L})$ & - & - & 12.5 & $\begin{array}{l}+0.4 \\
(P=0.19)\end{array}$ & $\begin{array}{l}-5.1 \\
(P=0.04)\end{array}$ \\
\hline Early & 22 & high & $27.3 \pm 3.7(22)$ & 9.9 & 72.1 \\
\hline pregnancy & 45 & low & $16.9 \pm 3.1(37)$ & 10.0 & 77.2 \\
\hline Difference $(H-L)$ & - & - & 10.4 & $\begin{array}{l}-0.1 \\
(P=0.84)\end{array}$ & $\begin{array}{l}-5.1 \\
(P=0.08)\end{array}$ \\
\hline
\end{tabular}

I In parenthesis the number of trials in which the energy intake was well defined and not only stated as high and low.

2 Coefficients of variation (calculated from residual mean square) of number of embryos alive per gilt and embryonic survival were $14.4,14.0,14.2$ and $12.4,12.6,12.8$ for rearing, flushing and early pregnancy respectively,

Table 12. Possible combinations of period of feeding and energy level (high $=\mathrm{H}$ and low $=\mathrm{L}$ ).

\begin{tabular}{lllr}
\hline Rearing period & Flushing period & Early pregnancy & Number of trials \\
L & L & L & 26 \\
L & L & H & 3 \\
L & H & L & 14 \\
L & H & H & 3 \\
H & L & L & 1 \\
H & L & H & 0 \\
H & H & L & 3 \\
H & H & H & 15 \\
\hline
\end{tabular}

and 14.0 for the combination LLL, LHL and HHH, respectively. A high constant level of energy was related to high embryonic mortality and to large number of ova shed. But the number of embryos per gilt was nearly the same as at constant low energy levels. The combination LHL seems to be most favourable in the short run. Though high-energy diets before mating increase ovulation, continuation of these dietary schemes causes greater loss of embryos (Anderson \& Melampy, 1972).

Embryonic survival did not differ significantly for pigs on different levels of protein during rearing or pregnancy (Svajger et al., 1972; Duée \& Etienne, 1974; Jones \& Maxwell, 1974; Hammel et al., 1976; Duée, 1977; Wahlstrom \& Libal, 1977). Protein requirements during pregnancy seems of minor significance compared with 
Table 13. Influence of energy level on two reproduction characteristics for the three most frequently studied combinations of treatments. Mean values in the same row bearing a common superscript are not different $(\mathrm{ab} P<0.05)( \pm$ separates mean and standard deviation $)$.

\begin{tabular}{|c|c|c|c|c|}
\hline $\begin{array}{l}\text { Sequence of } \\
\text { treatment }\end{array}$ & LLL & LHL & $\mathrm{HHH}$ & $\begin{array}{l}\text { Coefficient of } \\
\text { variation }(\%)^{2}\end{array}$ \\
\hline Duration of pregnancy (d) & $28.0 \pm 5.6$ & $28.1 \pm 5.6$ & $29.1 \pm 6.8$ & \\
\hline Number of treatments (n) & 26 & 14 & 15 & \\
\hline \multicolumn{5}{|c|}{ Intake of net energy ${ }^{1}(\mathrm{MJ} / \mathrm{d})$} \\
\hline - rearing & $16.4 \pm 3.0(22)$ & $17.9 \pm 3.5(10)$ & $27.0 \pm 2.5(13)$ & \\
\hline - flushing & $16.2 \pm 3.1(23)$ & $32.6 \pm 5.8(11)$ & $27.0 \pm 2.4(15)$ & \\
\hline - pregnancy & $17.0 \pm 2.4(22)$ & $18.1 \pm 3.4(11)$ & $27.4 \pm 2.5(15)$ & \\
\hline \multicolumn{5}{|l|}{ Number of embryos } \\
\hline alive per gilt & 9.90 & 10.75 & 9.84 & 12.4 \\
\hline Embryonic survival $(\%)$ & $78.7^{\mathrm{a}}$ & $77.6^{\mathrm{a}}$ & $70.3^{b}$ & 11.8 \\
\hline
\end{tabular}

' In parenthesis the number of trials in which the energy intake was well defined and not only stated as high and low.

2 Calculated from residual mean square.

energy (van Kempen, 1973). Pregnant sows will still grow on a maintenance scheme for non-pregnant sows. Explanations for this phenomenon are:

- an increased moisture retention of tissues

- a decreased maintenance requirement

- an increased utilization of nutrients (Busch, 1970).

\section{Acknowledgements}

The authors wish to thank Dr Ir M. W. A. Verstegen for the valuable comments and $\mathrm{Mr}$ J. C. Rigg for checking the English.

\section{References}

Aherne, F. X., R. J. Christopherson, J. R. Thompson \& R. T. Hardin, 1976. Factors affecting the onset of puberty, post-weaning estrus and blood hormone levels of Lacombe gilts. Can. J. Anim. Sci. 56: 681-692.

Aherne, F. X. \& M. A. Price, 1979. Relationship between age at puberty (first ovulation) and body composition at market weight in gilts. Proc. 30th Annual Meet. Eur. Ass. Anim. Prod. p. 5.11.

Anderson, L. L., 1974. Early embryonic development in the pig. J. Anim. Sci. 39: 986 (abstr.).

Anderson, L. L. \& R. M. Melampy, 1972. Factors affecting ovulation rate in the pig. In: D. J. A. Cole (Ed.), Pig production. Butterworths, London, pp. 329-366.

Bazer, F. W., A. J. Clawson, O. W. Robinson, C. K. Vincent \& L. C. Ulberg, 1968. Explanation for embryo death in gilts fed a high energy intake. J. Anim. Sci. 27: 1021-1026.

Boyd, H., 1965. Embryonic death in cattle, sheep and pigs. Vet. Bull. 35: 251-266.

Brooks, P. H. \& D. J. A. Cole, 1971. The effect of increasing feed intake for one day only during the oestrous period on the reproductive performance of sows. Anim. Prod. 13: 669-675.

Brooks, P. H. \& D. J. A. Cole, 1974. The effect of nutrition during the growing period and the oestrus cycle on the reproductive performance of the pig. Livestock Prod. Sci. 1: 7-20. 


\section{A. DEN HARTOG AND G. J. M. VAN KEMPEN}

Brooks, P. H., D. J. A. Cole \& P. Rowlinson, 1975. Studies in sow reproduction 3. The effect of nutrition between weaning and remating on the reproductive performance of multiparous sows. Anim. Prod. 20: 407-412.

Brooks, P. H. \& K. J. Cooper, 1972. Short Term nutrition and litter size. In: D. J. A. Cole (Ed.), Pig production. Butterworths, London, pp. 385-398.

Brooks, P. H., K. J. Cooper, G. E. Lamming \& D. J. A. Cole, 1972. The effect of feed level during oestrus on ovulation rate in the gilt. J. Reprod. Fert. 30: 45-53.

Burger, J. F., 1952. Sex physiology of pigs. Onderstepoort J. Vet. Sci. Anim. Ind. Suppl. 2.

Busch, B., 1970. Möglichkeiten zur Erhöhung der Fruchtbarheit von Sauen über die Fütterung. Tierzucht 24: 216-217.

Busch, B., 1976. Neue Erkenntnisse und Erfahrungen der Schweinefütterung in industriemäszige Anlagen und in Altbauten. Tierzucht 30: 122-124.

Christenson, R. K. \& J. J. Ford, 1979. Puberty and estrus in confinement-reared gilts. J. Anim. Sci. 49: 743-751.

Christenson, R. K. \& D. R. Zimmerman, 1966. Influence of level of energy on reproductive performance in the gilt. J. Anim. Sci. 25: 1267 (abstr.).

Christian, R. E. \& J. C. Nofziger, 1952. Puberty and other reproductive phenomena in gilts as affected by plane of nutrition. J. Anim. Sci. 11: 789 (abstr.).

Clark, J. R., R. A. Dailey, N. L. First, A. B. Chapman \& L. E. Casida, 1972. Effect of feed level and parity on ovulation rate in three genetic groups. J. Anim. Sci. 35: 1216-1222.

Clark, J. R., T. N. Edey, N. L. First, A. B. Chapman \& L. E. Casida, 1973. Effects of four genetic groups and two levels of feeding on ovulation rate and folliculair development in puberal gilts. $J$. Anim Sci. 36: 1164-1169.

Clawson, A. J., 1969. Proc. Ga. Nutr. Conf. p. 45.

Cooper, K. J., P. H. Brooks, D. J. A. Cole \& N. B. Haynes, 1973. The effect of feed level during the oestrus cycle on ovulation, embryo survival and anterior pituitary LH potency in the gilt. J. Reprod. Fert. 32: 71-78.

Cunningham, P. J., C. H. Naber, D. R. Zimmerman \& E. R. Peo, jr. 1974. Influence of nutritional regime on age at puberty in gilts. J. Anim. Sci. 39: 63-67.

Daily, R. A., J. R. Clark, N. L. First, A. B. Chapman \& L. E. Casida 9172. Effects of high and low feeding at two stages of the estrous cycle on follicular development in gilts from four genetic groups. $J$. Anim. Sci. 35: 1210-1215.

Dailey, R. A., J. R. Clark, N. L. First, A. B. Chapman \& L. E. Casida, 1975a. Loss of follicles during the follicular phase of the estrous cycle of swine as affected by genetic group and level of feed intake. J. Anim. Sci. 44: 835-841.

Dailey, R. A., J. R. Clark, N. L. First, A. B. Chapman \& L. E. Casida, 1975b. Effect of short-term 'flushing' on follicular development at estrous and ovulation rate of gilts of different genetic groups. J. Anim. Sci. 41: 842-847.

Dimov, J. 1963. The effect of nutrition on ovulation and embryonic development in Bulgarian White gilts. Anim. Breed. Abstr. 31, Abstr. 1373.

Duée, P. H. 1977. Influence d'une restriction azotée, a partir de $25 \mathrm{~kg}$ de poids vif sur les performances de reproduction de la truie. Journ. Rech. Porcine France: 193-198. INRA-ITP.

Duée, P. H. \& M. Etienne, 1974. Influence de l'alimentation pendant la croissance de la truie sur la maturité sexuelle et les performances de reproduction: résultats préliminaires. Journ. Rech. Porcine France: 43-48. INRA-ITP.

Du Mesnil du Buisson, F. \& J. P. Signoret, 1962. Influences de facteurs externes sur le déclenchement de la puberté chez la truie. Ann. Zootech. 11: 53-59.

Dutt, R. H. \& C. H. Chaney, 1968. Feed intake and embryo survival in gilts. Progr. Rep. Ky. Agric. Exp. Stn. No 176: 33 (Anim. Breed. Abstr. 37 (1969) 656; abstr. 3883).

Edey, T. N., J. R. Clark, N. L. First, A. B. Chapman \& L. E. Casida, 1972. Ovarian response to fasten following high and low planes of nutrition in pubertal gilts. J. Anim. Sci. 35: 1223-1227.

Emerson, D. D. \& D. M. Henricks, 1977. The effects of low levels of PMSG and flush feeding upon embryonic survival in gilts. Theriogenology 8: 281-291.

Englisch, H. G., G. Nitzsche \& U. Redel, 1971. Die Sauen leistungsgerecht füttern heiszt mehr Ferkel aufziehen und Futter rationell nutzen. Tierzucht 25: 11. 
Etienne, M. \& P. H. Duée, 1973. Effets respectifs des niveaux alimentaires pendant la croissance et le premier mois de gestation sur les performances de reproduction chez la truie nulliparae: résultats préliminaires. Ann. Zootech. 22: 453-462.

Etienne, M., P. H. Duée \& J. Lebost, 1976. Influence du niveau alimentaire entre le sevrage et la saille sur les performances de reproduction des truies multipares. Journ. Rech. Porcine France: 127-132. INRA-ITP.

Etienne, M. \& C. Legault, 1974. Influence de la race et du regime alimentaire sur la precocité sexuelle. Journ. Rech. Porcine France: 57-62. INRA-ITP.

Friend, D. W., 1973. Influence of dietary amino acids on the age at puberty of Yorkshire gilts. J. Anim. Sci. 37: 701-707.

Friend, D. W., 1976. Nutritional effects on age at puberty and plasma amino acid level in Yorkshire gilts and on chemical composition, nucleic acid, fatty acid and hydroxyproline contents of the uterus. $J$. Anim. Sci. 43: 404-412.

Friend, D. W., 1977. Effect of dietary energy and protein on age and weight at puberty of gilts. J. Anim. Sci. 44: 601-607.

Frisch, R. E., 1975. The physiological basis of reproductive efficiency. In: Meat annimals, growth and productivity, pp. 327-354.

Frobish, L. T. 1970. Effect of energy intake on reproductive performance and estrous synchronization of gilts. J. Anim. Sci. 31: 846-490.

Frobish, L. T. \& R. J. Gerrits, 1969. Effect of energy intake and oestrus synchronization on reproductive performance of gilts. J. Anim. Sci. 28: 873 (abstr.).

Goode, L., A. C. Warnick \& H. D. Wallace, 1965. Effect of dietary energy levels upon reproduction and the relationship of endometrial phosphatase activity to embryo survival in gilts. J. Anim. Sci. 24: 959963.

Gosset, J. W. \& A. M Sørensen Jr., 1959. The effect of two levels of energy and season on reproductive phenomena in gilts. J. Anim. Sci. 18: 40-47.

Günther, K. D., 1974. Zur Frage der Beeinflussung von Fortpflanzungsprozessen beim weiblichen Rind durch Grünfutter von intensiv gedüngten Produktionsflächen. Tierärztl. Umschau 29: 411-418.

Hafez, E. S. E., 1959. Reproductive failure in the sow. J. Anim. Sci. 18: 1178 (abstr.).

Hafez, E. S. E., 1960. Nutrition in relation to reproduction in sows. J. agric. Sci. 54: 170-178.

Haines, C. E., A. C. Warnick \& H. D. Wallace, 1959. The effect of two levels of energy intake on reproductive phenomena in Duroc Yersey gilts. J. Anim. Sci. 18: 347-354.

Hammel, D. L., D. D. Kratzer, G. L. Cromwell \& V. W. Hays, 1976. Effect of protein malnutrition of the sow on reproductive performance and on postnatal learning and performance of the offspring. $J$. Anim. Sci. 43: 589-597.

Hanly, S., 1961. Prenatal mortality in farm animals. J. Reprod. Fert. 2: 182-194.

Hansel, W. \& K. McEntee, 1977. Female reproductive processes. In: Dukes physiology of domestic animals, 9th ed., p. 1253-1297.

Hartog, L. A. den, 1980. De relatie voeding-vruchtbaarheid bij (opfok) zeugen. Dept. of Animal Nutrition, Agricultural University, Wageningen, $55 \mathrm{pp}$.

Herrmann, U. \& K. Richter, 1979. Untersuchungen zur Fütterung weiblicher Jungschweine-Einfluss der Energieversorgung und der Wachstumsintensität auf den Pubertätseintritt und die spätere Fruchibarheitsleistung. Tierzüchter 33: 132-135.

Holness, D. H., 1972. Aspects of puberty in the indigenous gilt. S. Afr. J. Anim. Sci. 2: 85-90.

Hughes, P. E. \& D. J. A. Cole, 1975. Reproduction in the gilt 1 . The influence of age and weight at puberty on ovulation rate and embryo survival in the gilt. Anim. Prod. 21: 183-189.

Jones, R. D. \& C. V. Maxwell, 1974. Effect of protein level on growth, nitrogen balance and reproductive performance in gilts. J. Anim. Sci. 39: 1067-1072.

Joosten, H. A. M., 1979. De invloed van voeding tijdens de opfok op de vruchtbaarheid van gelten. Dept. of Animal Nutrition, Agricultural University, Wageningen.

Kempen, G. J. M. van, 1973. De voeding van fokzeugen. Bedrijfsontwikkeling 4: 47-50.

Kempen, G. J. M. van, 1976. De invloed van het voederniveau op de vruchtbaarheid van opfokzeugen. (Not published.)

Kerk, P. van de \& Th. A. M. Elsinghorst, 1976. De invloed van het voederniveau op de vruchtbaarheid van opfokzeugen. CLO-studiedagen, Utrecht. 


\section{A. DEN HARTOG AND G. J. M. VAN KEMPEN}

King, J. W. B. \& G. B. Young, 1957. Maternal influences on litter size in pigs. J. agric. Sci. 48: 467-463.

Kirkpatrick, R. L., B. E. Howland, N. L. First \& L. E. Casida, 1967a. Some characteristics associated with feed and breed differences in ovulation rate in the gilt. J. Anim. Sci. 26: 188-192.

Kirkpatrick, R. L., B. E. Howland, N. L. First \& L. E. Casida, 1967b. Ovarian and pituitary gland changes in gilts on two nutrient energy levels. J. Anim. Sci. 26: 358-364.

Lamming, G. E., 1969. Nutrition and reproduction. In: D. Cuthbertson (Ed.), Nutrition of animals of agricultural importance, Part 1. The science of nutrition of farm livestock, p. 411-453.

Legault, C. 1973. Determinisme génétique de la précocité sexuelle du taux d'ovulation, et du nombre d'embryons chez la truie primiparé: héritabilité, effet d'heterosis. Journ. Rech. Porcine France: 147. 154. INRA-ITP, Paris.

Legault, C. \& J. Dagorn, 1973. Incidence de l'age à la première mise-bas sur la productivité de la truie. Journ. Rech. Porcine France: 227-237. INRA-ITP, Paris.

Libal, W. G., D. E. Wachholz \& R. C. Wahlstrom, 1972. Effect of energy level at estrus on gilt ovulation rate. J. Anim. Sci. 35: 1107 (abstr.).

Libal, G. W. \& R. C. Wahlstrom, 1970. The influence of energy during estrus on ovulation rate. 14th Swine Day Rep., S. Dak. Agric. Exp. Stn: 44.

Lodge, G. A. \& B. Hardy, 1968. Influence of nutrition during oestrus on ovulation rate in the sow. J. Reprod. Fert. 15: 329-332.

Lodge, G. A. \& R. M. McPherson, 1961. Level of feeding during early life and the subsequent reproductive performance of sows. Anim. Prod. 3: 19-28.

McCance, R. A. \& E. M. Widdowson, 1974. The determinants of growth and form. Proc. R. Soc. Lond. B 185: 1-17.

McGillivray, J. J., A. V. Nalbandov, A. H. Jensen, H. W. Norton \& D. E. Becker, 1962. Reproductive performance in gilts starved or fed different levels of energy. J. Anim. Sci. 21: 1005 (abstr.).

McGillivray, J. J., A. V. Nalbandov, A. H. Jensen, H. W. Norton, B. G. Harmon \& D. E. Becker, 1963. Effect of chanching energy intake on reproductive performance in gilts. J. Anim. Sci. 22: 112 (abstr.).

Moore, C. P., R. H. Dutt, V. W. Hays \& G. L. Cromwell, 1971. One-day vs 14-day flushing effects on reproduction in gilts. J. Anim. Sci. 32: 387-388 (abstr.).

Moore, C. P., R. H. Dutt, V. W. Hays \& G. L. Cromwell, 1973. Influence of one-day or conventional flushing on ovulation rate and litter size at 28 days gestation in gilts. J. Anim. Sci. 37: 734-738.

McPherson, R. M., F. D. Deb. Hovell \& A. S. Jones, 1977. Performance of sows first mated at puberty or second or third oestrus, and carcass assessment of oncebred gilts. Anim. Prod. 24: 333-342.

Myers, D. J. \& V. C. Speer, 1973. Effects of an antibiotic and flushing on performance of sows with shorts farrowing intervals. J. Anim. Sci. 36: 1125-1128.

Naber, C. N., P. J. Cunningham \& D. R. Zimmerman, 1972. Effect of high lysine corn vs. or CSN diet on age at puberty in the gilt. J. Anim. Sci. 35: 1122 (abstr.).

Naber, C. \& D. R. Zimmerman, 1971. One day vs. conventional 'flushing' for increasing ovulation rate in the gilt. J. Anim. Sci. 33: 1160 (abstr.).

Naber, C. N. \& D. R. Zimmerman, 1972. Influence of 'flushing' interval on ovulation rate in the gilt. J. Anim. Sci. 35: 1122 (abstr.).

O'Bannon, R. H., H. D. Wallace, A. C. Warnick, G. E. Combs, 1966. Influence of energy intake on reproductive performance of gilts. J. Anim. Sci. 25: 706-709.

Pay, M. G. \& T. E. Davies, 1973. Growth, food consumption and litter production of female pigs mated at puberty and at low body weights. Anim. Prod. 17: 85-91.

Pomeroy, R. W., 1960. Infertility and neonatal mortality in the sow. IV. Further observations and conclusions. J. agric. Sci. 54: 57-66.

Rerat, A. \& P. H. Duée, 1975. Ernährung und Reproduktion der Sau. Übers. Tierernähr. 3: 101-141.

Rigor, E. M., R. K. Meyer, N. L. First \& L. E. Casida, 1963. Endocrine differences associated with follicular development and ovulation rate in and energy intake. J. Anim. Sci. 22: 43-50.

Robertson, G. L., L. E. Casida, R. H. Grummer \& A. B. Chapman, 1951. Some feeding and management factors affecting age at puberty and related phenomena in Chester White and Poland China gilts. J. Anim. Sci. 10: 841-866.

Schilling, E. \& J. Schröder, 1977. Natürliche und induzierte Geschlechtsreife bei Jungsauen nach unterschiedlicher Aufzuchtfütterung. Tierzüchter 29: 53-56. 
Schneider, D. \& K. Bronsch, 1975. Zur Wirkung der Energieversorgung während der Trächtigkeit auf Gewichtsentwickelung und Reproduktionsleistung von Sauen. Tierzüchter 27: 483-485.

Schultz, J. R., V. C. Speer, V. W. Hays \& R. M. Melampy, 1965. Effect of feed intake on ovulation rate and embryonic mortality in swine. J. Anim. Sci. 24: 929 (abstr.).

Schultz, J. R., V. C. Speer, V. W. Hays \& R. M. Melampy, 1966. Influence of feed intake and progesteron on reproductive performance in swine. J. Anim. Sci. 25: 157-160.

Scofield, A., 1972. Embryonic mortality. In D. J. A. Cole: Pig production. Butterworths, London, pp. 367-383.

Self, H. L., R. H. Grummer \& L. E. Casida, 1955. The effects of various sequences of full and limited feeding on the reproductive phenomena in Chester White and Poland China gilts. J. Anim. Sci. 14: 573-592.

Short, R. E., D. R. Zimmerman \& L. J. Sumption, 1963. Heterotic influence on reproductive performance in swine. J. Anim. Sci. 22: 868 (abstract).

Sørensen, A. M. Jr., W. B. Thoman \& J. W. Gossett, 1961. A further study of the influence of level of energy and season on reproductive performance of gilts. J. Anim. Sci. 20: 347-349.

Staigmiller, R. B. \& N. L. First, 1973. The effect of a 'single feed flush' on ovulation rate in gilts. $J$. Reprod. Fert. 35: 573-575.

Staigmiller, R. B. \& D. L. Garbers \& N. L. First, 1972. The effect of energy intake and ICI 33828 on ovulation rate in swine. J. Reprod. Fert. 30: 317-319.

Svajger, A. J., D. L. Hammell, M. J. Degeeter, V. W. Hays, G. L. Cromwell \& R. H. Dutt, 1972. Reproductive performance of sows on a protein-restricted diet. J. Reprod. Fert. 30: 455-458.

Tassel, R., 1967. The effects of diet on reproduction in pigs, sheep and cattle. I. Plane of nutrition in pigs. Br. Vet. J. 123: 76-84.

Te Brake, J. H. A., 1975. Possible ways for increasing the productivity in sows and their merits and demerits. Rapport C261, 26th Ann. Meet. Eur. Ass. Anim. Prod.

Thompson, L. H. \& J. S. Savage, 1978. Age at puberty and ovulation rate in gilts in confinement as influenced by exposure to a boar. J. Anim. Sci. 47: 1141-1144.

Vanschoubroek, F., 1969. Actuele aspecten van de varkensvoeding. Tijdschr. Diergeneesk. 94: 14611476.

Varley, M. A. \& D. J. A. Cole, 1976. Studies in sow reproduction 4. The effect of level of feeding in lactation and during the interval from weaning to remating on the subsequent reproductive performance of the early-weaned sow. Anim. Prod. 22: 71-77.

Wahlstrom, R. C. \& G. W. Libal, 1977. Effects of dietary protein during growth and gestation on development and reproductive performance of gilts. J. Anim. Sci. 45: 94-99.

Webel, S. K. \& P. J. Dziuk, 1974. Effect of stage of gestation and uterine space on prenatal survival in the pig. J. Anim. Sci. 38: 960-963.

Wrathall, A. E., 1975. Reproductive disorders in pigs. Review series No 11 of the Commonwealth Bureau of Animal Health. Commonwealth Agricultural Bureau, Farnham Royal, England, $311 \mathrm{pp}$.

Zimmerman, D. R., H. G. Spies, H. L. Self \& L. E. Casida, 1958. The effect of glucose feeding on ovulation rate in Chester White gilts. J. Anim. Sci. 17: 1212 (abstr.).

Zimmerman, D. R., H. G. Spies, H. L. Self \& L. E. Casida, 1960a. Ovulation rate in swine as affected by increased energy intake just prior to ovulation. J. Anim. Sci. 19: 295-301.

Zimmerman, D. R., H. G. Spies, E. M. Rigor, H. L. Self \& L. E. Casida, 1960b. Effect of restricted feeding, crossbreeding and season of birth on age at puberty in swine. J. Anim. Sci. 19:687-694. 